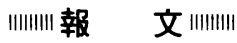

\title{
静岡県における胃癌標準化死亡比の地域差と食品・ 栄養摂取状況との関連
}

\author{
那 須 恵 子*1, 小 國 伊太郎*1, 金 谷 節 子*2, \\ 太田裕 一*3, 菅 民 郎*4 \\ *1静岡県立大学短期大学部食物栄養学科, ${ }^{* 2}$ 聖赫三方原病院栄養科, \\ *3静岡県対がん協会, *4(侏社会情報サービスシステム事業部
}

\section{Differences of Food Intake and Nutritional Status between the Areas with Low} and High Standardized Mortality Ratio for Stomach Cancer in Shizuoka Prefecture

Keiko Nasu*1, Itaro Oguni ${ }^{* 1}$, Setsuko Kanaya ${ }^{* 2}$, Yuichi Ota ${ }^{* 3}$ and Tamio Kan*4

${ }^{* 1}$ Department of Food and Nutrition Sciences, University of Shizuoka Hamamatsu College ;

${ }^{* 2}$ Seirei-mikatahara Hospital ; ${ }^{* 3}$ Shizuoka Cancer Society ; ${ }^{* 4}$ Social Survey Research Information Co., Ltd.

In order to clarify the differences in dietary habits between the inhabitants in the area with low standardized mortality ratio (SMR) for stomach cancer and those in the area with high SMR in Shizuoka Prefecture, a questionnaire survey was conducted among 407 males and 391 females aged 35 - 69 years who lived in the two areas in the autumn of 1982 . The intake of each food group (1st group : milk and daily products, eggs ; 2nd group : fishes and shellfishes, meats, legume ; 3rd group : vegetables, potatoes, fruits ; 4 th group : cereals, sugar and sweeteners, oil and beverages), nutritional status, PFC energy ratios and intake frequencies of rice, miso soup, fruit, milk and green tea in the low SMR area were compared with those in the high SMR area. Other factors related to physical conditions (age, height, weight, intensity of labor, occupation, etc.) were also compared. The characteristic features of dietary habits in the low SMR area were as follows.

1) Inhabitants in the low SMR area for stomach cancer took foods of the 2nd and 3rd groups, particularly fruits and vegetables, more often than those in the high SMR area.

2) The frequency of miso soup intake was higher among those of the low SMR area than those of the high SMR area. Moreover, the former used a greater variety of ingredients for the miso soup than the latter.

3) In the inhabitants of the low SMR area, there was a positive correlation between the intake of green tea and the factors considered to lower the stomach cancer risks such as intakes of fruits and vegetables and miso soup.

The above results suggest that the combined effects of the intake of green tea and that of the foods considered to lower the risk of stomach cancer possibly play a role in lowering SMR for stomach cancer.

Jpn. J. Nutr., 50 ( 3 ) 133 144 (1992)

はじめに

日本人の病による死亡は, 1981年以降死亡原因の第 1 位を占めている。その中で胃癌死亡率は年々減少傾向 にあるが, 現在, なお癌死亡全体の $1 / 4$ を占めており ${ }^{1)}$, その予防を考えることは重要なことと思われる。 Wynder らは, 人の癌の発生要因について疫学的に検討を行い, 男性の癌の $40 \%$, 女性の場合は $60 \%$ が食生活

Key words : SMR for stomach cancer, factor lowering risk of stomach cancer, green tea, survey of dietary life, Shizuoka prefecture

胃癌SMR, 胃癌低危険因子, 緑茶, 食生活調査, 静岡県 
に関係していると報告している2)。また Armstrong らは，多くの部位の癌の発生率や死亡率が食事やその他の 生活環境要因と深くかかわっていることを報告している3)。一方，最近，食品中の抗変異原物質や抗発癌物質 の存在も報告されており ${ }^{4,5)}$ ，食生活を含めた生活環境が癌の発生・進展に深くかかわっていることを示して (る6.7)。

著者らは，胃癌死亡率に影響を及ほす食生活要因について，抑制因子の面から検討を行う目的で，静岡県 中・西部地域の胃癌標準化死亡比（SMR）の著しく異なる地域の住民を対象に，食生活調査を実施した。その 結果，胃癌 SMR 低地域の緑茶摂取は高地域より多いことを認め, 胃癌 SMR の地域差に緑茶摂取量が関与して いることを報告した8)。そこで今回は更に，胃癌 SMR 低地域の食生活の特徴を明らかにするために，緑茶を

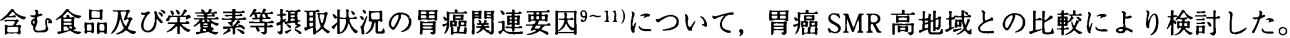

\section{調 查 方 法}

\section{1. 調査対象}

昭和44〜 57年の14年間の静岡県人口動態統計をもとに算出した胃癌 SMR より ${ }^{8)}$ ，胃癌 SMR 低地域として， 川根町・中川根町・本川根町の 3 町（K 町）50世帯及び島田市（S 市）101世帯，また高地域として，O町277 世帯を，抽出率0.5 10\%で選挙人名簿より無作為抽出し，そのうちの $35 ６ 9$ 歳の男女を調查対象とした（図 1 )。今回解析に用いた対象地域の総人口，SMR及び対象者の年齢（5歳階級）別内訳を，地域別に示した （表 1 ）。なお，低地域の対象者数は少ないので，K町及びS 市を合わせて解析に用いた。

\section{2. 調查時期及び調查方法}

調查は昭和57年10月末から11月中旬の間に，保健婦または栄養士による面接聞き取り法により実施した。

\section{3. 調查項目}

調查は, 生活歴, 既往歴, 家族歴，嗜好品拱取状況，食習慣・栄養素等摃取状況に関して質問表を作成し行 った。なお，食習慣・栄養素等摂取状況については，健康增進センター等で使用されているアンケート式食物 摄取状況調査法（厚生省健康指標策定委員会作成）を使用した。

本報告では，生活歷の中から身体状況（身長，体重，肥満度），労働状況（職業，労働強度，労働による精 神的ストレス, 労働時間, 暇な時 間）及び健康意識について，食習 慣・栄養素等摂取状況の中からみ そ汁, 牛乳, 果物, 漬け物, 塩辛 い物の各摂取頻度, 米飯の摄取杯 数, みそ汁の具の種類数，食事の 規則性について集計した結果を資 料として用いた。栄養素等撖取状 況は, 食品群別損取点数（1 群： 乳・乳製品, 卵, 2 群：魚介, 肉 類, 豆・豆製品， 3 群：野菜，い も類, 果物, 4 群：穀物, 砂糖, 油脂，その他の嗜好品)，栄養素

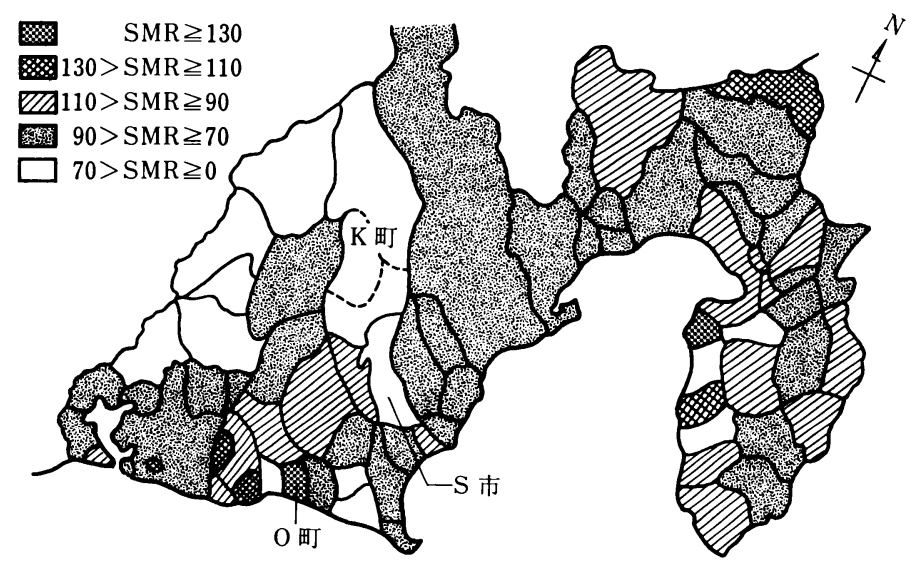

図 1 静岡県における胃癌(女性)の市町村別 SMR 分布図(1969 1982) 
表 1 地域の性別人口, 胃㾌 SMR 及び対象者の年齢分布

\begin{tabular}{|c|c|c|c|c|c|c|c|c|}
\hline \multirow[t]{3}{*}{ 対 象 } & \multicolumn{6}{|c|}{ 低地域 } & \multirow{2}{*}{\multicolumn{2}{|c|}{$\frac{\text { 高地域 }}{\text { O 町 }}$}} \\
\hline & \multicolumn{2}{|c|}{$\mathrm{K}$ 町 } & \multicolumn{2}{|c|}{ S市 } & \multicolumn{2}{|c|}{$\mathrm{K}$ 町 $+\mathrm{S}$ 市 } & & \\
\hline & 男性 & 女性 & 男性 & 女性 & 男性 & 女性 & 男性 & 女性 \\
\hline 人口*1(人) & 10,250 & 10,543 & 35,164 & 36,889 & 45,414 & 47,432 & 5,677 & 5,982 \\
\hline $\mathrm{SMR}^{* 2}$ & $38.6^{* *}$ & $42.7^{* *}$ & $71.2^{*}$ & $68.6^{* *}$ & $60.6^{* *}$ & $60.7^{* *}$ & 96.3 & 132.4 \\
\hline \multicolumn{9}{|c|}{ 対象者年齢分布 $* 3$} \\
\hline 35～39歳 & $5(8.3)$ & $5(8.1)$ & $12(11.3)$ & $18(16.8)$ & $17(10.2)$ & $23(13.6)$ & $27(11.2)$ & $21(9.5)$ \\
\hline 40～44歳 & $4(6.7)$ & $11(17.7)$ & $13(12.3)$ & $14(13.1)$ & $17(10.2)$ & $25(14.8)$ & $25(10.4)$ & $41(18.5)$ \\
\hline 45～49歳 & $14(23.3)$ & $8(12.9)$ & $17(16.0)$ & $18(16.8)$ & $31(18.7)$ & $26(15.4)$ & $43(17.8)$ & $38(17.1)$ \\
\hline 50～54歳 & $11(18.3)$ & $11(17.7)$ & $22(20.8)$ & $22(20.6)$ & $33(19.9)$ & $33(19.5)$ & $46(19.1)$ & $52(23.4)$ \\
\hline 55～59歳 & $9(15.0)$ & $7(11.3)$ & $18(17.0)$ & $18(16.8)$ & $27(16.3)$ & $25(14.8)$ & $49(20.3)$ & $45(20.3)$ \\
\hline 60 ６4歳 & $6(10.0)$ & $8(12.9)$ & $16(15.1)$ & $13(12.1)$ & $22(13.3)$ & $21(12.4)$ & $34(14.1)$ & $19(8.6)$ \\
\hline 65～69歳 & $11(18.3)$ & $12(19.4)$ & $8(7.5)$ & $4(3.7)$ & $19(11.4)$ & $16(9.5)$ & $17(7.1)$ & $6(2.7)$ \\
\hline 計 & $60(100)$ & $62(100)$ & $106(100)$ & $107(100)$ & $166(100)$ & $169(100)$ & $241(100)$ & $222(100)$ \\
\hline
\end{tabular}

*1 昭和57年 4 月 1 日現在の推計人口

*2 ** $p<0.01,{ }^{*} p<0.05$ (O 町との SMR の地域差検定結果) ${ }^{12)}$

*3 数值は人数，（）内は\%

等摂取量 (エネルギー摄取量, たん白質, 脂質, 糖質摄取量, 塩分摄取量), 及び栄盖素のエネルギー比率 （たん白質，脂質，糖質の総エネルギーに対するエネルギー比率；以下，PFCエネルギー比と略す）を算出し た。この調査法では，エネルギー，たん白質及び糖質摄取量の推定值については実際の摄取量との相関関係が 認められているが, 脂質については相関関係がみられず，脂質摄取量の推定值は実際の摄取量よりも低く見積 もられることが報告されている ${ }^{13)}$ 。そこで調查に当たって, 油脂の䝟食内容に関する設問のうち, 従来, 油脂 使用料理（サラダ等のドレッシングやシチュー等の油脂の使用量の多い料理）を, “1 日に何回食べますか” と質問していた項目を，朝，昼，夕食の契食回数に改め，更に 1 回に食べている油脂使用料理数も合わせて質 問する方法に改めることにより，できるだけ実際の摄取量が反映されるようにした。肥満度は，身長及び体重 を用いてブローカ・桂氏変法 ${ }^{14}$ により標準体重を算出し，体重が標準体重の $90 \%$ 未満をやせ・やややせ，90～ 109\%を普通， $110 \%$ 以上をやや肥満・肥満として，3 段階に分類した。不明回答の者は分析から除外し，年龄 構成を補正した Mantel-Haenszel $\chi^{2}$ 検定 ${ }^{15)}$ 及び共分散分析法により解析を行った。

結 果

1. 食品・生活要因の地域間の比較

食品及び生活要因の各項目について，性別に地域差の有無を観察した。有意に差の認められた項目は，男性 では果物を“毎日 1 個以上”摂取している者が胃癌 SMR 低地域（以下，低地域とする）のほうに胃癌 SMR 高 地域（以下，高地域とする）よりも多くみられ（ $p<0.01 ）$ ，みそ汁を“1 日 2 杯以上”攝取している者も低 地域のほうが高地域よりも多かった $(p<0.05)$ （表 2$)$ 。野菜攝取量も朝食及び昼食時に“普通に食べる”ま たは“たっぷり食べる”者が，低地域のほうが高地域よりも多かった $(p<0.01)$ 。女性でも男性と同様に果 物を“毎日 1 個以上”掑取している者が低地域のほうに高地域よりも多く $(p<0.01)$ ， みそ汁を“1 日 2 杯 以上”摄取している者も低地域のほうに高地域よりも多くみられた $(p<0.01)$ 。野菜損取量では昼食（ $p<$ 
表 2 食品要因の比較

\begin{tabular}{|c|c|c|c|c|c|c|c|c|c|}
\hline \multirow{2}{*}{\multicolumn{2}{|c|}{ 項 }} & \multirow{2}{*}{ 目 } & \multirow{2}{*}{ カテゴリー } & \multicolumn{3}{|c|}{ 男 } & \multicolumn{3}{|c|}{ 女性 } \\
\hline & & & & 低地域*1 & 高地域*1 & 統計学的検定 & 2 低地域*1 & 高地域*1 & 統計学的検定 $* 2$ \\
\hline & 乳 & 攝 取 & 1 本以上/日 & $38(23.2)$ & $58(24.1)$ & $\chi^{2}=0.02$ & $29(17.3)$ & $60(26.9)$ & $\chi^{2}=3.59$ \\
\hline & & & 飲まない・時々 & $126(76.8)$ & $183(75.9)$ & ns & $139(82.7)$ & $163(73.1)$ & ns \\
\hline \multirow[t]{2}{*}{ 果 } & 物 & 摄 取 & 1 個以上/日 & $117(70.5)$ & $95(39.6)$ & $\chi^{2}=35.33$ & $129(77.7)$ & $101(45.5)$ & $\chi^{2}=53.34$ \\
\hline & & & 食べない・半個位 & $49(29.5)$ & $145(60.4)$ & $p<0.01$ & $37(22.3)$ & $121(54.5)$ & $p<0.01$ \\
\hline \multirow[t]{2}{*}{ み } & そ 汁 & - 摂 取 & 2 杯以上/日 & $86(52.1)$ & $96(39.8)$ & $\chi^{2}=5.24$ & $79(47.0)$ & $72(32.3)$ & $\chi^{2}=8.55$ \\
\hline & & & 1 杯以下/日 & $79(47.9)$ & $145(60.2)$ & $\hat{p}<0.05$ & $89(53.0)$ & $151(67.7)$ & $\tilde{p}<0.01$ \\
\hline \multirow[t]{2}{*}{ みう } & そ汁の具 & 具の種類 & 3 種類以上 & $97(58.8)$ & $90(37.3)$ & $\chi^{2}=18.02$ & $107(63.7)$ & $82(36.8)$ & $\chi^{2}=29.23$ \\
\hline & & & 2 種類以下 & $68(41.2)$ & $151(62.7)$ & $n<001$ & $61(36.3)$ & $141(63.2)$ & $p<0.01$ \\
\hline \multirow[t]{2}{*}{ 漬 } & け物 & 捸 取 & ほとんど毎日 & $118(71.5)$ & $153(63.7)$ & $\chi^{2}=2.06$ & $124(73.8)$ & $142(64.0)$ & $\chi^{2}=3.94$ \\
\hline & & & 時々 - 数回/週 & $47(28.5)$ & $87(36.3)$ & ns & $44(26.2)$ & $80(36.0)$ & $p<0.05$ \\
\hline \multirow[t]{2}{*}{ 塩 } & 辛 & 心 物 & 1 回以上/週 & $54(32.7)$ & $69(29.0)$ & $\chi^{2}=0.53$ & $38(22.9)$ & $40(18.0)$ & $\chi^{2}=1.67$ \\
\hline & & & 食べない・時々 & $111(67.3)$ & $169(71.0)$ & ns & $128(77.1)$ & $182(82.0)$ & ns \\
\hline \multirow{2}{*}{\multicolumn{2}{|c|}{ 野菜摂取 }} & 取（朝） & 普通・たっぷり & $101(60.8)$ & $112(46.5)$ & $\chi^{2}=7.30$ & $98(58.7)$ & $69(41.3)$ & $\chi^{2}=3.64$ \\
\hline & & & 少し・食べない & $65(39.2)$ & $129(53.5)$ & $\tilde{p}<0.01$ & $108(48.6)$ & $114(51.4)$ & ns \\
\hline \multirow{2}{*}{\multicolumn{2}{|c|}{ 野菜攝取 }} & 取（昼） & 普通・たっぷり & $120(72.3)$ & $142(59.2)$ & $\chi^{2}=6.82$ & $125(74.9)$ & $135(61.1)$ & $\chi^{2}=7.52$ \\
\hline & & & 少し・食べない & $46(27.7)$ & $98(40.8)$ & $\hat{p}<0.01$ & $42(25.1)$ & $86(38.9)$ & $p<0.01$ \\
\hline \multirow{2}{*}{\multicolumn{2}{|c|}{ 野莱摄取 }} & 取（夕） & 普通・たっぷり & $142(85.5)$ & $194(80.8)$ & $\chi^{2}=1.26$ & $154(92.2)$ & $191(86.0)$ & $\chi^{2}=4.50$ \\
\hline & & & 少し·食べない & $24(14.5)$ & $46(19.2)$ & ns & $13(7.8)$ & $31(14.0)$ & $p<0.05$ \\
\hline \multirow[t]{2}{*}{ P } & ルコー & ル摄取 & ほとんど毎日 & $87(53.7)$ & $118(50.4)$ & $\chi^{2}=0.11$ & & & \\
\hline & & & 飲まない·数回/週 & $75(46.3)$ & $116(49.6)$ & . & & & \\
\hline
\end{tabular}

*1 数值は人数，（）内は\%

*2 年齡を補正した Mantel-Haenszel $\chi^{2}$ 検定結果：ns は有意差なし

$0.01 ）$ 及び夕食時（ $p<0.05 ） に “$ 普通に食べる”ま たは“たっぷり食べる”者が低地域のほうに高地域よ りも多く認められた。漬け物攝取頻度にも差がみられ， 漬け物を“ほとんど毎日”摂取している者が低地域の

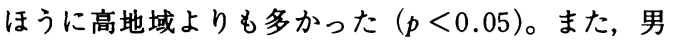
女とも共通して低地域に多く認められたみそ汁の摄取 方法を, みそ汁の具の種類数からみると（図 2 ), 低 地域では 3 種類以上の具を使用している者が高地域よ りも男女とも多く認められた $(p<0.01)$ 。次に穀物 の摂取を地域別米飯摄取杯数からみると, 低地域の米 飯攝取杯数（平均土標準偏差：男性 $5.1 \pm 1.6$; 女性 $4.4 \pm 1.3$ ) と高地域の米飯捸取杯数（男性 $5.1 \pm 1.6$

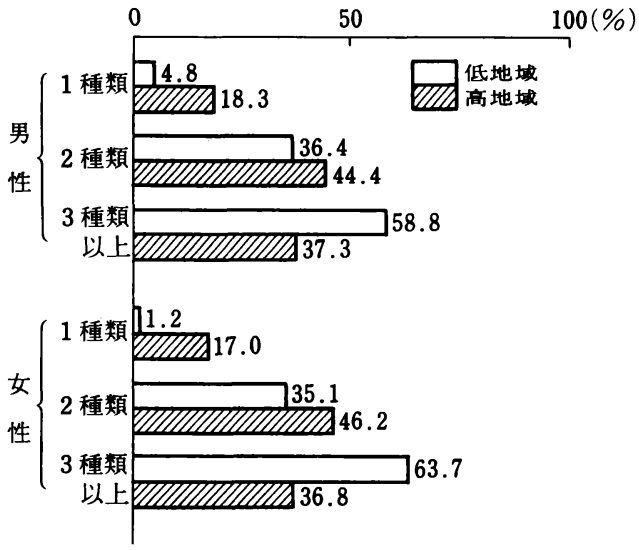

図 2 みそ汁の具の種類

；女性 4.5土1.4）との間に有意な差は認められなかった。

男性の生活歴の項目に関しては, 食事を“規則的に食べている”者が高地域よりも低地域のほうに多く（p 
表 3 生活要因の比較

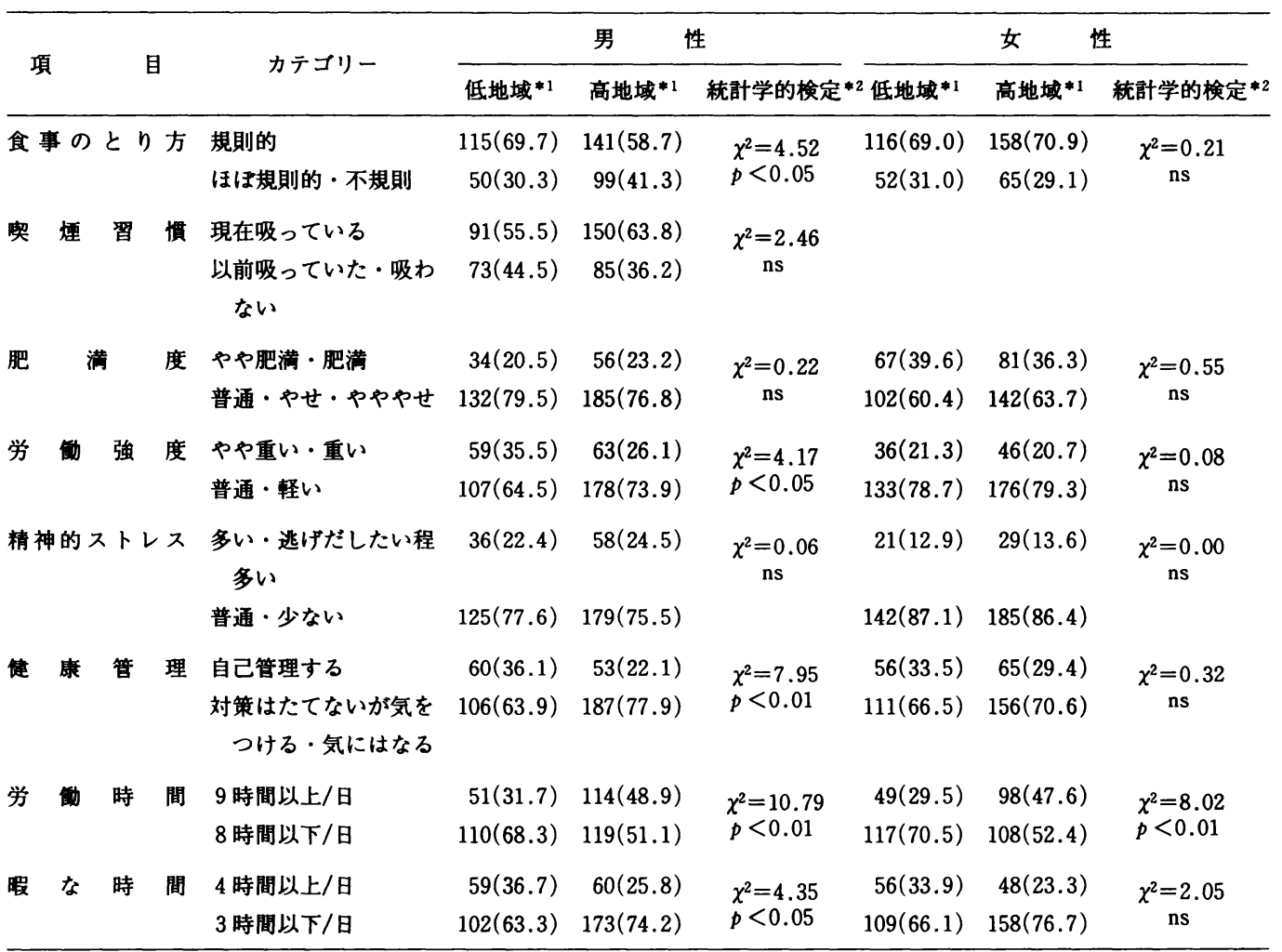

*1 数值は人数，（）内は\%

*2 年龄を補正した Mantel-Haenszel $\chi^{2}$ 検定結果：ns は有意差なし

表 4 食品群別攝取点数の比較

\begin{tabular}{|c|c|c|c|c|c|}
\hline & 項目 & カテゴリー & 低地域"1 & 高地域*1 & 統計学的検定 ${ }^{* 2}$ \\
\hline \multirow{8}{*}{ 男 性 } & 1 群 & 1.3 以上 & $57(34.3)$ & $56(23.2)$ & \multirow{2}{*}{$\begin{array}{l}\chi^{2}=5.13 \\
\stackrel{p}{<}<0.05\end{array}$} \\
\hline & & 1.3末満 & $109(65.7)$ & $185(76.8)$ & \\
\hline & 2 群 & 2.7 以上 & $134(80.7)$ & $128(53.1)$ & \multirow{2}{*}{$\begin{array}{l}\chi^{2}=31.09 \\
p<0.01\end{array}$} \\
\hline & & 2.7未満 & $32(19.3)$ & $113(46.9)$ & \\
\hline & 3 群 & 1.7 以上 & $131(78.9)$ & $85(35.3)$ & \multirow{2}{*}{$\begin{array}{l}\chi^{2}=71.27 \\
p<0.01\end{array}$} \\
\hline & & 1.7未満 & $35(21.1)$ & $156(64.7)$ & \\
\hline & 4 群 & 14.4 以上 & $87(52.4)$ & $122(50.6)$ & \multirow{2}{*}{$\begin{array}{c}\chi^{2}=0.07 \\
\text { ns }\end{array}$} \\
\hline & & 14.4末満 & $79(47.6)$ & $119(49.4)$ & \\
\hline \multirow{8}{*}{ 女 性 } & 1 群 & 1.0 以上 & $31(18.3)$ & $60(27.0)$ & \multirow{2}{*}{$\underset{\mathrm{ns}}{\chi^{2}=2.65}$} \\
\hline & & 1.0 未満 & $138(81.7)$ & $162(73.0)$ & \\
\hline & 2 群 & 2.5 以上 & $107(63.3)$ & $117(52.7)$ & \multirow{2}{*}{$\begin{array}{l}\chi^{2}=4.22 \\
p<0.05\end{array}$} \\
\hline & & 2.5未満 & $62(36.7)$ & $105(47.3)$ & \\
\hline & 3 群 & 1.7 以上 & $121(71.6)$ & $95(42.8)$ & \multirow{2}{*}{$\begin{array}{l}\chi^{2}=32.7 \\
p<0.01\end{array}$} \\
\hline & & 1.7未満 & $48(28.4)$ & $127(57.2)$ & \\
\hline & 4 群 & 12.4 以上 & $82(48.5)$ & $113(50.9)$ & \multirow{2}{*}{$\underset{\mathrm{ns}}{\chi^{2}=0.01}$} \\
\hline & & 12.4末満 & $87(51.5)$ & $109(49.1)$ & \\
\hline
\end{tabular}

*1 数值は人数,（）内は\%

*2 年齢を補正した Mantel-Haenszel $\chi^{2}$ 検定結果：ns は有意差なし 
$<0.05)$, 労働強度が “やや重い・重い”と回答した者も低 地域に多かった $(p<0.05)$ 。更に健康管理については, “気 をつけて自己管理する”者の割合が低地域に多く（ $p<$ 0.01), 胃癌 SMR 低地域のほうが健康に対する関心が高い傾 向が認められた（表 3 )。しかし女性ではこれらの項目に統 計的な差異はみられなかった。また労㗢強度と関係する労働 時間では，1 日 9 時間以上働く者が男女とも高地域に低地域 よりも多く $(p<0.01)$, 一方, 暇な時間（自分の自由にな る時間）が 1 日 4 時間以上ある者は, 低地域の男性が高地域 よりも多かった $(p<0.05)$ 。契煙習慣, アルコール摄取, 肥満度及び精神的ストレスには地域間の差が認められなかっ た。

\section{2. 食品群及び栄菱素等摄取状況の地域間の比較}

4 群別食品摄取状況, 栄養素等摂取状況の地域差の有無に ついて性別に観察した。

食品群別摄取状況では, 男性で 4 群を除く 3 つの食品群の 摄取点数に地域差が認められた（表 4 ）。地域ごとにその摂 取状況をみると, 食品群別摂取点数では低地域のほうが高地 域よりも，1群 $(p<0.05), 2$ 群及び 3 群 $($ 各々 $p<0.01)$ の㠌取点数が多かった。女性でも 2 群 $(p<0.05)$ 及び 3 群 $(p<0.01)$ の食品摄取点数に有意な差が認められ, 低地域 のほうが高地域よりも多かった。

栄養素等摄取量では, 男女ともすべての項目に地域差が認 められなかった（表 5 )。

\section{3. 農業従事者における地域間比較}

調查地域の主な職業は, 低地域では男女とも69\%以上が農 業に従事しており（男性 69.9\%；女性 69.0\%), 次いで会 社員・公務員 (男性 $21.7 \%$; 女性 $22.6 \%$ ), 商工自営業 （男性 $3.6 \%$; 女性 $3.0 \%$ ), その他（男性 $3.0 \%$; 女性 $4.2 \%$ ) となっていた。また高地域でも農業が最も多く（男 性 $42.5 \%$; 女性 $41.3 \%)$, 次いで男女で順番が異なるが, 会社員・公務員（男性 $25.4 \%$; 女性 $22.9 \%$ ), 商工自営業 （男性 $24.2 \%$ ；女性 $23.8 \%$ ）となっていた。

このように，職業構成に地域差が認められた。食生活は, 職業の偏りによる社会・経済的背景の相違に影響されること も予想される。そこで, 両地域で最も大きな割合を占める農 業従事者のみを対象として, 胃癌SMR低・高地域間の食品及

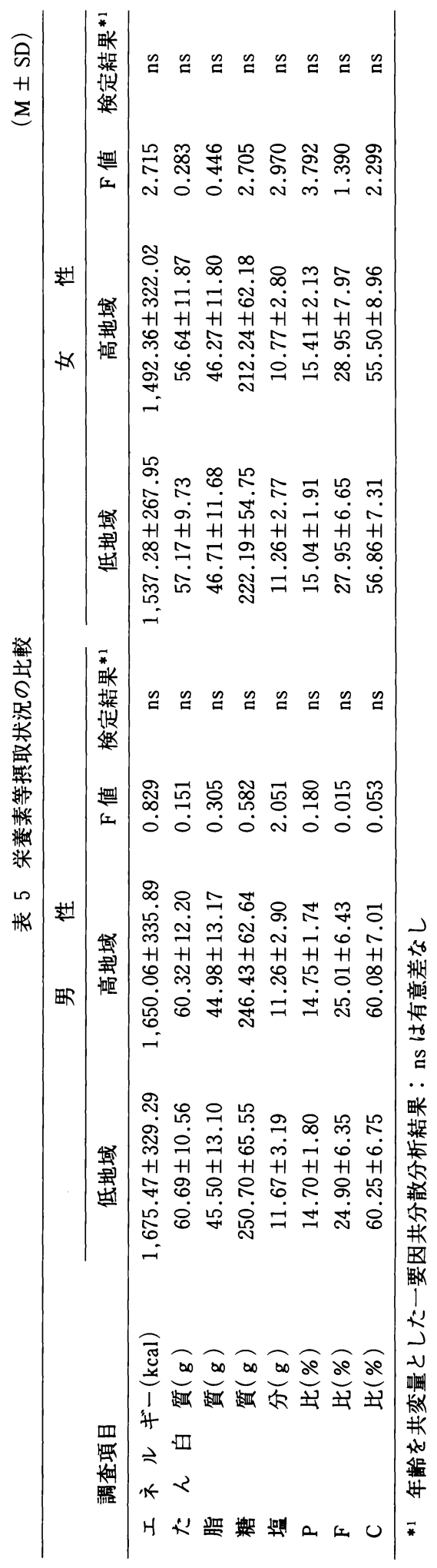




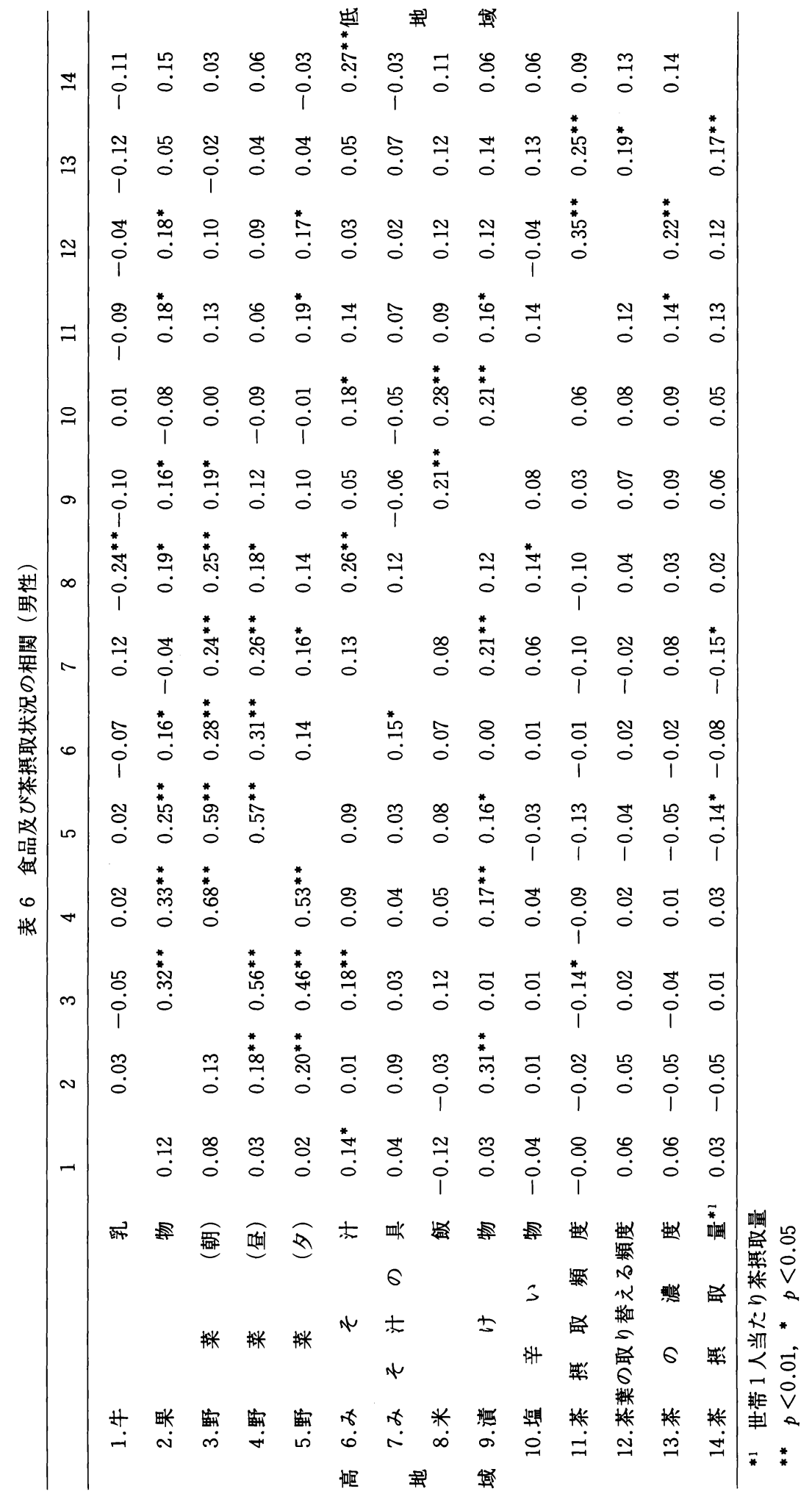




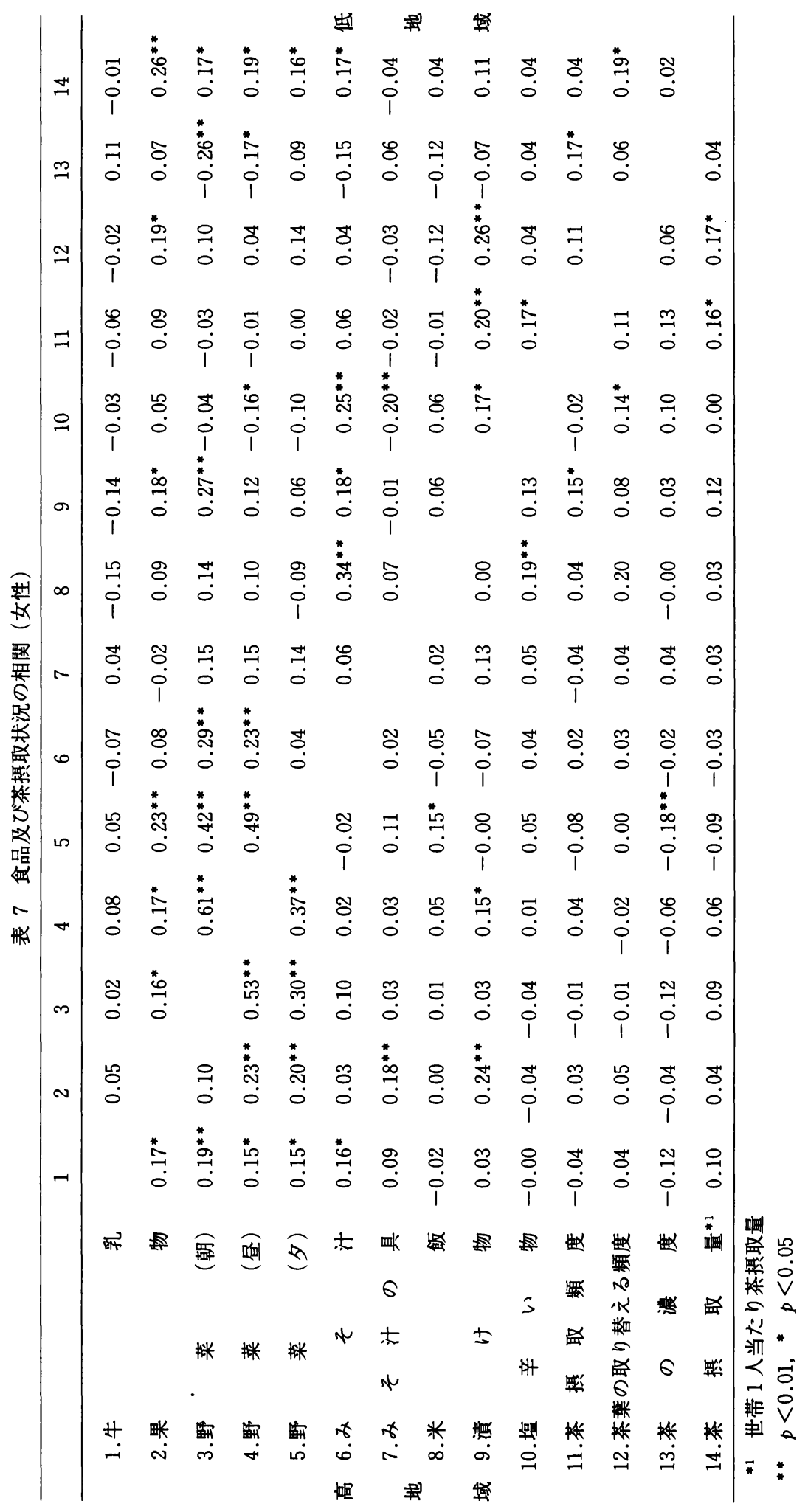


び生活要因の差について検討した。男性では, 果物 $\left(\chi^{2}=28.79, p<0.01 ; \chi^{2}\right.$ 検定結果 $)$, みそ汁 $\left(\chi^{2}=\right.$ 5.24, $p<0.05)$, 滇け物 $\left(\chi^{2}=6.39, p<0.05\right)$ の各摄取頻度, みそ汁の具の種類 $\left(\chi^{2}=7.06, p<0.01\right)$, 及び自由になる時間（层な時間） $\left(\chi^{2}=9.92, p<0.01\right)$ に, 対象者全体の結果と同様の傾向が認められた。 女性では, 果物 ( $\chi^{2}=37.5, p<0.01$; Mantel-Haenszel $\chi^{2}$ 検定結果), みそ汁 $\left(\chi^{2}=11.88, p<0.01\right)$ の各 提取頻度, 朝食 $\left(\chi^{2}=5.24, p<0.05\right)$ 及び昼食時 $\left(\chi^{2}=5.33, p<0.05\right)$ の野菜摄取量及びみそ汁の具の種 類 $\left(\chi^{2}=17.22, p<0.01\right)$ に, 対象者全体の結果と同様の傾向が認められた。食品群の摄取状況についても, 男女とも 2 群（男性 $\chi^{2}=18.58, p<0.01$; 女性 $\chi^{2}=5.21, p<0.05 ）$ 及び 3 群（男性 $\chi^{2}=33.9, p<0.01$ ; 女性 $\chi^{2}=20.97, p<0.01 ）$ の攝取点数が，低地域のほうに高地域よりも多く，対象者全体の結果とほほ同 粎の傾向が認められた。すなわち, 胃癌 SMR 低・高地域間にみられた食品・栄養要因の差異は, 職種の違い によるものではないことが示唆された。

\section{4. 食品及び茶摄取状況の相関}

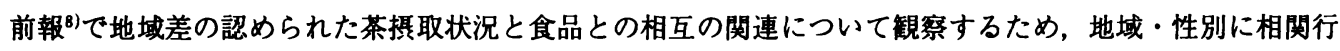
列を作成した（表 6,7$)$ 。

茶の摄取状況と食品間の関係をみると, 男性の低地域では, 茶の摄取頻度と果物摄取頻度 $(r=0.18)$ ・野 菜摄取量 $($ 夕 $r=0.19) \cdot$ 漬け物摃取頻度 $(r=0.16)$ との間（各々 $p<0.05 ）$ に, 茶葉の取り替える頻度と 果物摄取頻度 $(r=0.18)$ ・野菜摄取量（夕r=0.17）との間（各々 $p<0.05 ） に$, 茶摄取量とみそ汁摄取頻 度 $(r=0.27, p<0.01)$ との間に正の相関が示された。一方高地域では, 茶摄取頻度と野菜摄取量（朝 $r=$ -0.14）との間に, 茶摄取量と野菜摄取量 $($ 夕 $r=-0.14) \cdot$ みそ汁の具の種類 $(r=-0.15)$ との間に負の 相関が示された (各々p<0.05)。茶の浱度と食品摂取状況との間には, 两地域とも相関を示さなかった。

女性の低地域では，茶の摄取頻度と漬け物 $(r=0.20, p<0.01) \cdot$ 塩辛い物 $(r=0.17, p<0.05)$ の搨取 頻度との間に, 茶葉の取り替える頻度と果物 $(r=0.19, p<0.05)$ ・漬け物 $(r=0.26, p<0.01)$ の摄取頻 度との間に, 茶摄取量と果物摄取頻度 $(r=0.26, p<0.01)$ - 野菜捸取量（朝 $r=0.17$; 昼 $r=0.19 ;$ 夕 $r$ $=0.16$, 各々 $p<0.05) \cdot$ みそ汁摄取頻度 $(r=0.17, p<0.05)$ との間に正の相関が示されたが, 茶の濰度と 野菜摄取量（朝 $r=-0.26, p<0.01$; 昼 $r=-0.17, p<0.05 ）$ との間には負の相関を示した。高地域では, 茶の攝取頻度と漬け物摄取頻度との間 $(r=0.15, p<0.05)$, 茶葉の取り替える頻度と塩辛い物の摄取頻度 $(r=0.14, p<0.05)$ との間に正相関を示したが, 茶の浱度と野菜摄取量（夕ｒ=-0.18,p<0.01）との間 には負の相関を示した。茶搨取量と食品との間には相関がみられなかった。

\section{考察}

胃癌と食生活との関係については, これまでに多くの疫学的研究が行われている。本研究では, 静岡県下に おける胃癌SMRの地域差を胃癌危険因子と考えられている食品及び生活要因との関連から解析した。胃整低危 険因子としては牛乳，果物，緑黄色野菜等が報告されている ${ }^{10.11)}$ 。本報告でも，胃癌 SMR 低地域では高地域 と比較し，果物や野菜類をよく捸取しており，これらを含む 3 群の食品類の摄取量が多く，従来の報告と一致 した傾向が示された。またみそ汁の摂取頻度については，過去の疫学的研究ではその多量摄取が塩分の過剩摄 取につながることから，胃癌の高危險因子と考えられていだ ${ }^{16}$ が，近年の報告では，低危険因子として見直さ れてきている17)。これについては，みそ汁の具として使用される緑黄色野菜や大豆中のプロテアーゼ阻害郕等 が抑制因子として考えられている。本報告でも胃癌 SMR 低地域では具のたっぷり入ったみそ汁を高頻度に捸 
取している傾向が認められ；先の報告を支持する結果が得られた。

高危険因子の 1 つとして, 穀類の多量摂取が考えられている。柳井らは, 胃癌群のほうが対照群に比べて 1 日 7 杯以上の米飯攝取者が多いと報告している ${ }^{18)}$ 。また胃癌危険因子としての米飯攝取量を 1 日 9 杯以上とす る報告もある ${ }^{19)}$ 。本報告の調査対象集団の米飯攝取量は胃癌危険因子の量的問題からみるとかなり少なく, 50 歳以上の年龄層でやや地域差がみられたものの, 年齡を補正した全対象者での地域差は認められなかった。高 塩食品の摂取についても, 多くの疫学的研究より高危険因子と考えられており ${ }^{10 ~ 20)}$, 最近の報告では胃癌死亡 と塩分撕取量との間に明らかな相関が認められている21)。本研究では，女性において低地域のほうが高地域よ りも漬け物搷取頻度が多かったが, 塩分摄取量の推定値には差が認められなかった。栄養素と胃癌との関係に ついては, 瀬木らによって 1 日の総摃取エネルギー, 肉・乳・卵・油脂からのエネルギー及び動物性たん白質 攝取量が少なく, 款類からのエネルギー及び糖質エネルギー比の多い国ほど胃癌の死亡率が高く, 糖質/脂質 比が高危険因子として考えられている22 が, 本報告では栄養素等摂取状況に関する項目について男女とも地域 差が認められなかった。胃癌 SMR 低地域の食品攝取状況の特徴は, 胃癌低危険因子である果物・野菜類をよ く摃取していることであった。

茶の椇取状況と胃癌危険因子の食品類との関係については, 胃癌 SMR 低地域では男女とも茶の摂取と果物 及び野菜類の摂取とが正の相関を示したが，胃癌 SMR 高地域の男性では茶の摂取と果物及び野菜類の搷取と は負の相関を示し, 女性では茶の搨取と高塩食品とが正の相関を示し, 明らかに茶の攝取状況と食品摂取状況 のかかわり方において地域差が認められた。これらのことからは, 緑茶の摃取が果物や野菜類等の胃癌の予防 的食物要因と独立して，胃癌 SMR を低下させる要因としてかかわっているかどうかを断定することができな いが, 動物実験で示されている緑茶の直接あるいは間接的発癌抑制作用 ${ }^{23,24)}$ を考え合わせると, 緑茶摂取と食 習慣及び生活習慣の要因が輻軼して，胃癌 SMR を低下させる可能性が示唆された。

ストレスと癌についても動物実験により因果関係が報告されている25)。本報告では, 労働による精神的スト レスは労働強度や労働時間による影響を受けやすいと考え ${ }^{26)}$, これらの要因の地域間比較を行った。労働強度 では低地域の男性に労働強度が重いと回答した者が多かったが, 労働による精神的ストレスには地域差がみら れなかった。労動状況に関する農業者のみの解析においては労働強度及び労働時間に差がみられないことから， これらの要因の地域差は職業構成の差によるものと考えられた。

\section{要 約}

静岡県における胃癌標準化死亡比 (SMR) 低地域及び高地域の住民の食生活の差異を明らかにし, 胃癌 SMR を低下させる食生活要因を検討するために, 両地域の35～69歳の住民（男性 407 人, 女性 391人）を対 象に，1982年秋に質問紙による食生活調査を行った。調査は，4つの食品群（ 1 群：乳・乳製品, 卵； 2 群： 魚介類, 肉類, 豆類 ; 3 群 : 野菜類, いも類, 果物類 ; 4 群: 穀物, 砂糖・甘味類, 油脂, 嗜好品類) 及び栄 盖素等椇取状況，総搷取エネルギーに対するたん白質・脂質・糖質のエネルギー比率，米飯・みそ汁・果物・ 牛乳・緑茶等の食品摂取頻度, 及びその他の身体的要因 (年齡, 身長, 体重, 労働強度, 職業等) について実 施した。その結果, 胃癌 SMR 低地域では次のような特徴が明らかになった。

1）胃癌 SMR 低地域の人々は高地域の人々より，2・3 群の食品摂取が多く, 特に果物, 野菜類をよく掑 取していた。

2）胃癌 SMR 低地域の人々は高地域の人々より，みそ汁の摂取頻度が多く，みそ汁中に多種類の具を使用 
していた。

3）胃癌 SMR 低地域では，茶の摄取状況と胃癌低危険因子と考えられている果物，野菜，みそ汁等の食品 摄取との間に正の相関が認められた。

以上より, 茶の摂取と胃癌低危険因子の食品㠌取とが相互にかかわり合って, 胃癌 SMR の低下に関連して いるかもしれないという可能性がうかがわれた。

本調查にご協力いただきました静岡県衛生部，島田保健所，並びに関係市町村の皆様に深謝いたします。

文

\section{献}

1）長谷川敏彦：わが国における癌対策の歴史，医学のあゆみ，146，694７00（1988)/idem.：わが国の “癌”および “癌患者” の現状と将来予測, ibid., 701 706（1988）

2) Wynder, E. L. and Gori, G. B. : Contribution of the environment to cancer incidence, an epidemiologic exercise, J. Natl. Cancer Inst., 58, 825 832 (1977)

3) Armstrong, B. and Doll, R. : Environmental factors and cancer incidence and mortality in different countries, with special reference to dietary practices, Int. J. Cancer, 15, 617 631 (1975)

4) Ames, B. N. : Dietary carcinogens and anticarcinogens, oxigen radicals and degenerative diseases, Science, 223, 1256 1264 (1983)

5) McMichael, A. J. : Dietary influences upon human carcinogenesis, Food Technology in Australia, 36, 460 465 (1984)

6) Haenszel, W., Kurihara, M., Segi, M. and Lee, R. K. C. : Stomach cancer among Japanese in Hawaii, J. Natl. Cancer Inst., 49, 969 988 (1972)

7) Wynder, E. L. : Dietary habits and cancer epidemiology, Cancer, 43, 1955 1961 (1979)

8) Oguni, I., Nasu, K., Kanaya, S., Ota, Y., Yamamoto, S. and Nomura, T. : Epidemiological and experimental studies on the antitumor activity by green tea extracts, Jpn. J. Nutr., 47, 93 102 (1989)

9) Wynder, E. L., Kmet, J., Dungal, N. and Segi, M. : An epidemiological investigation of gastric cancer, Cancer, 16, 1461 1496 (1963)

10）平山 雄：胃癌の疫学, 胃と腸， 3, 787 796（1968）

11）平山 雄 : Effect of frequent consumption of green-yellow vegetables commonly observed to reduce the risk of colon and stomach cancer, 日本癌学会総会記事第44回総会 (東京), p.57 (1985)

12）福富和夫，橋本修二：標準化死亡比に関する考察，日本公衛誌，36，155～160（1989）

13）森本絢美, 高瀬幸子, 秦 鴻四, 細谷憲政：簡易食物調査による栄養素量の測定, 栄養学雑誌, 35 , 235 245 (1977)

14）松浦千文, 川越和子, 重信卓三, 中丸澄子, 松下 弘, 西本幸男: 大学生の肥満に関する研究, 保健の 科学, 21, 769 773 (1979)

15）福富和夫：マンテルヘンツェルの検定，日循協誌，24，104１05（1989）

16）平山 雄：胃癌の疫学, 日本臨床, 26, 1829 1832（1968）

17) Hirayama, T. : Relationship of soybean paste soup intake to gastric cancer risk, Nutrition and Cancer, 3 , 223 233 (1982)

18）柳井晴夫, 吉本泰彦, 高木廣文, 豊川裕之, 前田和甫, 栗田英男：胃癌の Risk Factor に関する統計的 分析, 日本公衛誌, 24, 547 556（1977）

19）加藤育子, 富永祐民：胃癌と栄養・食事, 公衆衛生, 51, 197２02（1987）

20) Tajima, K. and Tominaga, S. : Dietary habits and gastro-intestinal cancers, A comparative case-control study of stomach and large intestinal cancers in Nagoya, Japan, Jpn. J. Cancer Res. (Gann), 76, 705 716 
(1985)

21）津金昌一郎, 津田充有, 倉島由紀子, 渡辺 昌：胃癌の多要因発がん機構に対する横断的疫学研究一二 トロソ化合物及び食塩, 日本癌学会総会記事第50回総会 (東京), p.432 (1991)

22）瀨木三雄, 野家裕子：胃癌と腸癌・乳癌の国別死亡率と食物条件との関係, 日本癌学会総会記事第36回 総会 (東京), p.274（1977）

23）中村好志, 富田 熟：茶の抗突然変異・抗癁作用/村松敬一郎編：茶の科学, pp.131 144 (1991) 朝 倉書店, 東京

24）小國伊太郎：疫学的にみた茶の癌予防効果と抗腫瘍作用/村松敬一郎編：茶の科学, pp.144〜153 (1991）朝倉書店, 東京

25）手嶋秀毅, 久保千春, 井上貞久, 永田頌史, 今田義郎, 横山 宸, 吾郷晋浩, 中川哲也, 池見酉次郎： 移植癌とストレス, Jpn. J. of Psychosom. Med., 19, 373〜377（1979）

26）上畑鉄之丞：疲労調查の方法, 労㗢衛生, 30, 17 23（1989）

(受付：平成 3 年 5 月 27 日) 